
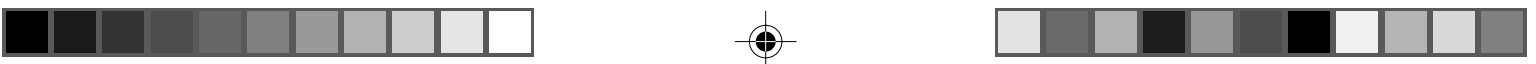

\title{
KASPAR VILLADSEN
}

\section{SKABELSEN AF DET MODERNE SUBJEKT}

\author{
Magt og subjektivitet hos Weber, Elias og Foucault
}

\begin{abstract}
Vi mener i hvert fald, at legemet, det adlyder ingen andre love end dets egen fysiologis, og at det unddrager sig historien. Endnu en fejltagelse; legemet er fanget $\mathrm{i}$ en række styreformer, som tildanner det; det har altid været udsat for arbejdsrytmer, for hvile, for fester; det beruses af gifte - fødevarer eller værdier, kostvaner eller moralpåbud mellem hinanden [...]. Historien er 'virkelig' i samme udstrækning, som den indfører det diskontinuerte i selve vor væren (Foucault 2001:69).
\end{abstract}

Det har været et centralt anliggende i antropologisk forskning at udfordre det moderne menneskes selvforståelse af sin egen kulturform som overlegen, universel og essentielt „humanistisk“. Ved at stille vestlig kultur i kontrast til fremmede kulturer er vores forståelse af rationalitet, modernitet, udvikling, den vestlige kulturs suverænitet m.v. blevet sat under pres. Dette kritiske arbejde har også søgt at udfordre forestillingen om „det autonome individs“ universalitet, og en række bidrag har argumenteret for, at dette er en moderne vestlig eller eurocentrisk konstruktion (bl.a. Taylor 1989; La Fontaine 1985; Comaroff \& Comaroff 2001). Det er en kritik af forestillingen om individet som en selv-omsluttet, selv-bestemmende og selv-transparent størrelse, der blandt andet kan spores tilbage til Durkheims begreb ,individkulten“, det moderne samfunds rituelle fejring af individets helliggjorte autonomi. En række antropologiske, etnografiske og sociologiske bidrag har vist, hvordan bestemte persontyper, subjekter eller roller opstår og reproduceres i specifikke sociale praksisser og institutioner (bl.a. Mauss 1985; Mead 1934; Goffman 1962). Hermed stilles der indirekte spørgsmålstegn ved fundamentale kategorier, som det moderne samfund bruger i sin selvbeskrivelse, såsom personlig autonomi, frihed, rettigheder, interesser, suverænitet og selvrealisering.

Den kritiske historiske sociologi kan siges at have et parallelt projekt, og her tillader jeg mig i første omgang at sammenstille en række beslægtede tænkere 

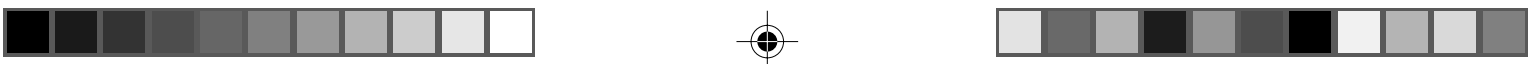

som foreslået af blandt andet Szakolczai (2000) og Krieken (2003). Det drejer sig om Max Weber, Nobert Elias og Michel Foucault, som alle har bidraget til at udfordre vores forestilling om det moderne, autonome individ ved hjælp af historien. Her er det ikke den kulturelle fremmedhed, som bruges som kritisk modbillede, men påvisningen af, hvordan fundamentale kategorier såsom rationalitet, fornuft og individualitet er opstået historisk ud af „lidet ærværdige“ institutioner, magtkampe og tilfældigheder. Mens antropologer har vist kontingensen og det ikkeuniverselle i vores moderne kultur ved at beskrive „det fremmede“ - enten i andre lande og kulturer eller i form af alternative livsformer i vestlige samfund bruger disse historiske sociologer historiens fremmedhed til at ryste forestillingen om det autonome individ og dets ,frisatte“ rationalitet.

I moderne historieskrivning har det været almindeligt at tilskrive opkomsten af frie og autonome individer oplysningen, frisættelsen fra standshierarkier, sekulariseringen, etableringen af et frit marked og af en „,borgerlig offentlighed“. Ud af disse moderne institutioner skulle et individ med en ,frisat" fornuft have fået lov til at træde frem. I kontrast til denne oplysningsbegejstrede historieskrivning står oplysningskritikere, som nægter at tale om en „frisættelse“ og i stedet hævder, at det moderne individ ikke selv er ophav til dets rationalitet. I stedet for at bruge historien til at bekræfte os i vores naturliggjorte selvbeskrivelser bruger de historien til at fremvise det ofte problematiske historiske ophav til moderne begreber om humanisme, autonomi, individualitet, selvbevidsthed og fornuft. Artiklen vil vise, hvordan den kritiske historiske sociologis „fremmedgørende“ effekt i forhold til vores kulturelle selvforståelse er parallel med den antropologiske relativisering gennem kulturel komparation og kontrastering. Begge stiller de grundlæggende spørgsmål ved vores begreb om det autonome individ, men via forskellige veje.

\section{Weber, Elias og Foucault sammen?}

Denne artikel vil for det første vise, hvordan Weber, Elias og Foucault sammen kan belyse forestillingen om det autonome individ. Den vil vise, hvordan de tre hver især kan læses som forskellige bidrag til en kritisk arkæologi over det moderne subjekt - som historiseres og hermed bliver en kontingent størrelse. Vi skal videre se, at Weber, Elias og Foucault på forskellig vis destabiliserer og decentrerer det autonome individ ved i deres substantielle analyser at angribe forskellige aspekter af dets rationalitet. For det andet vil artiklen diskutere analysestrategisk, hvordan vi kan bedrive historisk dekonstruktion af individ og rationalitet. Her vil artiklen nuancere begrebet om kritisk historisk sociologi ved at betone de forskelle, som adskiller de tre tænkeres historiske kritik, herunder især forskellen mellem en historisk sociologi (hos Weber og Elias) og den genealogiske analyse (hos 

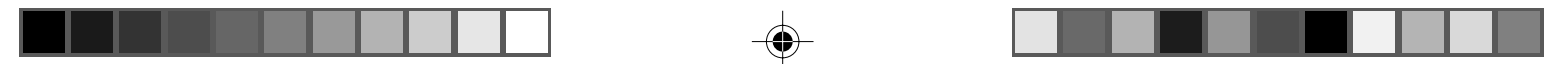

Foucault). Det bliver her klart, at den historiske opløsning af det autonome individ udspringer af forskellige traditioner og tjener forskellige formål hos de tre. Lad os dog først se på lighedspunkterne mellem Weber, Elias og Foucault.

For det første anlægger Weber, Elias og Foucault alle en mere eller mindre ekspliciteret modernitetskritik, idet de har undersøgt de ,uærværdige“ institutioner og former for social orden, hvorfra det frie, autonome individ er opstået. De benytter alle et kritisk greb, som påviser, hvordan det moderne, rationelle, udspringer af, eller viderefører, elementer fra det førmoderne og irrationelle. Hermed fremviser deres analyser ubekvemme kontinuiteter for den oplysningshistorie, som hævder et radikalt brud mellem det, vi betragter som det uoplyste, traditionelle og religiøse på den ene side, og det oplyste, moderne og sekulariserede på den anden. Mens oplysningstænkere har fremhævet, hvordan frie, autonome borgere er opstået i kraft af deres frisættelse fra stand, kirke, tradition og uvidenhed, har de tre vendt blikket mod disciplinerende og lukkede institutioner. Weber har interesseret sig for religiøse sekter, Elias for de europæiske „hofsamfund“ og Foucault for disciplinære institutioner såsom fængsler, galehuse, skoler og hospitaler. De interesserer sig således alle for, hvad man med Goffman kunne kalde „totale institutioner".

For det andet er Weber, Elias og Foucault fælles om at gennemføre ophavsanalyse af det moderne subjekt og dets rationalitet. De arbejder alle ud fra en genealogisk metode, som søger at opspore de historiske elementer, som indgår i det, der senere kommer til at fremstå som naturligt og universelt. Foucault har mest eksplicit formuleret denne strategi, men den fælles inspiration fra Nietzsche betyder, at også Webers og Elias' undersøgelser fremviser genealogiske træk. Historiske fænomener må opløses i deres konstituerende elementer og processer, og dette gælder også for det moderne individ. Hos Weber betragtes subjektet som formet i kraft af „etiske praksisser“ for livsførelse, hos Elias som indlejret $\mathrm{i}$ „sociale figurationer", og hos Foucault opløses subjektet i genealogisk aflæselige magt-viden-regimer. Alle tre tager de som udgangspunkt, at overgangen fra det traditionelle til det moderne samfund medfører, at selvet bliver objekt for en intensiveret skeptisk refleksion, styring og selvstyring. De er således fælles om at beskrive, hvordan der samme med det moderne samfund opstår en særlig mennesketype, som i en ny forstand objektiverer sig selv - hvad enten det er som udøver af verdsliggjort kaldsarbejde, som objekt for civiliseret selvovervågning eller som genstand for disciplinære interventioner og videnskabelige diskurser.

Endelig er der, for det tredje, hos Weber, Elias og Foucault en stærk betoning af magt, når de iagttager det moderne subjekt og dets opkomst. Når subjekter formes i kraft af historiske praksisser og ved at indgå i sociale relationer, er magten altid til stede. I Webers sociologi er udgangspunktet, at magt og magtbårne 

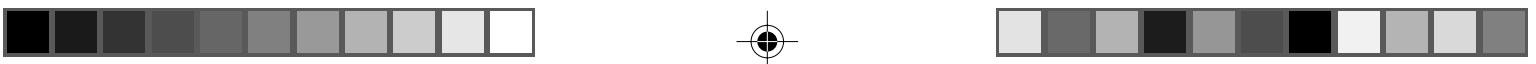

interesser er en uadskillelig del af social handling. Individet indgår altid i social samhandlen med forskellige ressourcer og har hermed forskellige muligheder for at „sætte sin vilje igennem trods den andens modstand“. Hos Elias er magten også på spil, når mennesker indgår i gensidige afhængighedsrelationer - de såkaldte figurationer. Disse udgør relativt træge strukturer af sociale relationer, som dog holdes i bevægelse af kampen om fordeling af status og ressourcer mellem de involverede aktører. Og i Foucaults analytik får magten en produktiv og allestedsnærværende karakter - den er til stede i vores viden, i vores relation til hinanden og i vores relation til os selv, idet spørgsmålet er, hvordan viden, magt og subjektivitet forbindes.

Hvis de tre teoretikere er fælles om en historisk decentrering af det autonome individ, gør de det imidlertid med forskelligt fokus. Hos Weber retter interessen sig især mod fremkomsten af det moderne rationelle (økonomiske) subjekt, og hvilken rolle religion spiller i denne proces. Hos Elias er fokus især på dannelsen af, hvad vi kan kalde det civiliserede, selvovervågende menneske, og han tildeler her livsbetingelserne i de tidlige europæiske hofsamfund en afgørende rolle. Og hos Foucault udfoldes problematikken i form af en række genealogier over forskellige aspekter ved det moderne menneskes erfaring af sig selv, blandt andet hvordan teknologisk-diskursive strategier har sat skel mellem galskab/ fornuft, afvigelse/norm og seksualitet/perversion. Vi skal i det følgende kort se på Webers, Elias’ og Foucaults mest indflydelsesrige værker, nemlig Webers Den protestantiske etik og kapitalismens ånd, Elias' The Court Society og Civilising Process samt Foucaults Overvågning og straf, for at diskutere, hvordan de kan bidrage til at belyse vores tematik. Dernæst foretager artiklen en diskussion af, hvad det vil sige at bedrive historisk dekonstruktion af det autonome individ, og overvejer styrker og svagheder i de tre teoretikeres tilgange. Vi skal i de følgende afsnit se, hvordan Weber, Elias og Foucault alle kan læses som modernitetskritikere, der udpeger ,ubekvemme kontinuiteter“.

\section{Max Webers „store“ modernitetskritik}

Der har været givet forskellige bud på, hvad der udgør Webers centrale anliggende. Nogle hævder, at det primære tema er de historisk kulturelle betingelser for den vestlige kapitalismes opkomst, og at Webers arbejde først og fremmest skal forstås i relation til striden mellem modstridende økonomiske skoler i hans samtid (Collins 2000; Bild 1989). På linje med samtidige tyske økonomihistorikere kritiserede Weber de neoliberale økonomer for at anskue det frie marked og den rationelle markedsaktør som ahistoriske fænomener. De plæderede i stedet for nødvendigheden af at identificere de sociale institutioner og betingelser, der afgjorde, 

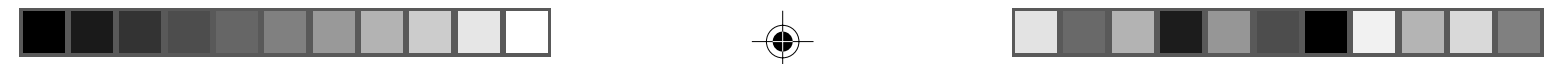

hvorvidt og i hvilken forstand et marked overhovedet kunne opstå. Webers interesse for det sociale historiske grundlag for kapitalismens opkomst kan læses i dette lys. Collins erklærer ligefrem: „Hele hans sociologi er i en vis forstand ikke andet end økonomiens institutionelle del, der gør sig fri som et selvstændigt videnskabsfelt" (Collins 2000: 46).

En alternativ Weber-læsning hævder derimod - bemærkelsesværdigt for vores nærværende tema - at hans egentlige anliggende er spørgsmålet om, hvilken mennesketype der vil opstå ud af bestemte sociale ordener (se bl.a. Hennis 1983; Mommsen 1987). Når Weber analyserer sociale institutioner, sker det ifølge Hennis altid med udgangspunkt i den samme overvejelse: Hvilken type menneske har størst chance for at opstå ud af disse institutioner? Jeg vil her abonnere på den sidstnævnte læsning, som kan finde støtte hos Weber selv. I en interessant passage siger Weber, at hans hovedinteresse i Den protestantiske etik og kapitalismens ånd ikke var kapitalismens udbredelse, men den „,menneskelighed“, som blev frembragt af kombinationen af religiøse og økonomiske faktorer: „Det var ikke den ekspansive fremvækst af kapitalismen, som udgjorde kernen i min interesse, men udviklingen af den menneskelighed, som blev frembragt i kraft af sammentræffet mellem religiøse og økonomisk betingede faktorer" (Weber $\mathrm{i}$ Hennis 1983:148). ${ }^{1}$

I denne tolkning er Webers religionssociologiske undersøgelser og mere generelle sociologi altså ikke centreret om rationalisering som sådan eller om kapitalismens udbredelse i sig selv, men snarere om, hvilken personlighedstype der fremmes af bestemte sociale ordener. Mommsen (1987:39) fremhæver på linje hermed, at det ikke er nogen tilfældighed, når Weber understreger, at enhver sociologi i sidste instans må placere individet som det centrale referencepunkt for sin fortolkning og analyse. Således kan vi sige, at Webers sociologi ikke blot ønsker at tage sit udgangspunkt i en fortolkning af individers subjektive meningstilskrivning, men desuden - og måske vigtigere - sætter sig som opgave at afdække bestemte personlighedstypers historisk-institutionelle formationsbetingelser.

Hvorvidt Weber har rationaliseringsprocessen som sit centrale tema eller dannelsen af særlige personlighedstyper, skal dog næppe afgøres ved et enten-eller. Tværtimod kan man læse de to temaer som to sider af samme problematik, nemlig spørgsmålet om, hvilke begrænsninger og muligheder „,den moderne vesterlandske kultur' rummer for skabelsen af autonome og etisk ansvarlige individer. For at blive i stand til at besvare dette spørgsmål gennemfører Weber en rekonstruktion af den særlige vestlige rationalismes tilblivelseshistorie, som sammenlignes med andre kulturers udvikling. Jeg vil i lyset af denne Weber-læsning først se på Webers essay Den protestantiske etik og kapitalismens ånd. Dette essay er ofte blevet læst som en analyse af, hvordan den protestantiske etik virker ind på 
rationaliseringen af det økonomiske liv og hermed som et bidrag til diskussionen om kapitalismens opkomst. I denne sammenhæng vil jeg imidlertid betone, hvordan teksten indgår i Webers overvejelser om skabelsen af det moderne subjekt og vilkårene for at være menneske i det moderne samfund.

Den måske mest overraskende og afgørende pointe i Den protestantiske etik og kapitalismens ånd er påvisningen af en positiv forbindelse mellem askese og berigelse - eller endnu mere generelt - påvisningen af, hvordan moderne rationalitet vokser ud af institutionaliseringen af asketiske praksisser. Dette genealogiske fokus på askesen optræder først hos Nietzsche (1999, 3. afh.), og Szakolczai fremhæver, at Weber anvender Nietzsches genealogiske tilgang længe før Foucault (Szakolczai 2000:109). I Webers opkomstanalyse af „den kapitalistiske ånd“ udpeges to genealogiske løbebaner, nemlig den religiøse askese og de kapitalistiske teknikker. Det første element er det overraskende, som optager det meste af Den protestantiske etik og kapitalismens ånd, mens det andet allerede var beskrevet af andre historikere. Man bør overveje, skriver Weber, „om ikke hele modsætningen mellem verdensfremmedhed, askese og kirkelig fromhed på den ene side og deltagelse i det kapitalistiske erhvervsliv på den anden burde ophæves og tværtimod forvandles til et indre slægtskab"(Weber 1995:22).

Lad os i dette lys kort se på Webers analyse i Den protestantiske etik og kapitalismens ånd og den modernitetsanalyse, som kan udledes heraf. En indgang til dette essay er det modsætningspar, som Weber andetsteds opstiller mellem på den ene side den aktive askese, der virker verdenstransformerende, „en Guds bestemt handlen som Guds værktøj“, og på den anden side „mystikkens kontemplative frelsesbesiddelse" (Weber 2003c:325). Den aktive askese kommer til udtryk ved en rationel udformning af tilværelsen, hvor man handler i og $p a ̊$ verden $i$ et verdsligt kald, mens mystikken derimod former sig som en radikal flugt fra verden i form af kontemplation. Protestantismen er idealtypisk kendetegnet ved netop den aktive askese, hvis krav om selvkontrol og selvfornægtelse utilsigtet medfører en rationaliseret livsførelse og de heraf følgende moderne eksistensbetingelser.

Weber bruger Jean Calvins prædestinationslære til at opstille en idealtype for den protestantiske etik: Gud har kun udvalgt et fåtal til frelsen, men han har ikke fundet det for godt at meddele hvem. Den psykologiske usikkerhed, som fulgte af den manglende vished, søgte calvinisterne især at imødegå ved at indskærpe utrætteligt kaldsarbejde som middel til at opnå denne vished: „Den 'helliges' liv var udelukkende rettet mod et overjordisk mål, nemlig saligheden, men netop derfor var det i sit dennesidige forløb helt igennem rationaliseret og behersket af det altovervejende synspunkt: at øge Guds ry på jorden“ (Weber 1995:77). Prædestinationslæren afstedkom på denne måde et aktivt program for livsførelse baseret på systematisk selvkontrol og selvfornægtelse. 

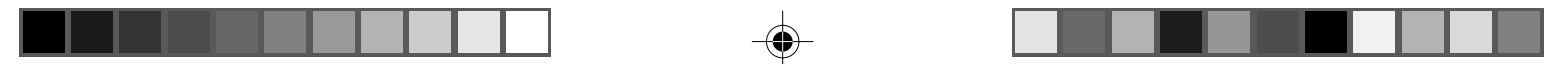

Webers pointe er nu, at der sker en udspredning af kaldsetikken, som medfører en transformation af samfundslivet. Rationaliseringen af livsførelsen vandrer ud i det verdslige hverdagsliv, som den begynder at gennemtrænge: ,Denne særlige livsstil, forskellig fra den ,naturlige“, blev afkrævet de hellige på religiøst grundlag, og den udspillede sig - og det er det mest afgørende - ikke længere uden for verden i munkefællesskabet, men inden for verden og dens ordninger" (op.cit.:102). Det afgørende er imidlertid, at der bliver tale om en verdsliggjort kaldsetik, som i stigende grad mangler sin værdimæssige begrundelse. De religiøse værdier dør ud, men den ,ejendommelige pligt til sin gerning“ lever videre som et inderliggjort program for livsførelsen: „Puritaneren ville være kaldsmenneske vi er $n ø d t$ til at være det" (op.cit.:121).

I Webers analyse antager den frie, ikke-religiøse og oplyste handlen, som skulle karakterisere det moderne samfund, nu en tvangsmæssig, religiøs og ureflekteret karakter. Den moderne rationalitet viser sig at være funderet i religion og bliver i denne forstand irrationel. Hermed sættes Webers egne kategorier og distinktioner under pres. Det bliver svært at opretholde et klart skel mellem det religiøse og det sekulære, mellem det irrationelle og det rationelle, mellem tradition og modernitet. På denne måde kan Den protestantiske etik læses som en kritisk dekonstruktion af oplysningsfortællingen og dens kategorier. Påstanden om en bevægelse fra tradition, vane, religiøsitet og overtro mod modernitet, refleksion og oplyst fornuft sættes på spil. I stedet vises, hvordan religion som en art rutiniseret ufornuft er dybt indlejret i den sekulariserede modernitet.

Den protestantiske etik kan også læses som et led i Webers diagnose af eksistensbetingelserne i det moderne, uddifferentierede samfund. Bogen beskriver, hvordan økonomien så at sige løsrives fra sin religiøse fundering, idet de praksisser og meningssystemer, som skaber den rationelle kapitalisme, ikke længere reproduceres med reference til religiøse værdier. Økonomien bliver i stedet en selvkørende, rationaliseret „værdisfære“. Weber hævder andre steder, at der med det moderne samfund udspaltes en række sådanne værdisfærer: økonomi, politik, videnskab, religion, æstetik og erotik. Religionen ophører med at levere endegyldige begrundelser, og verden kommer til at bestå af sideordnede værdisfærer, som står ,,i uløselig kamp med hinanden“( (Weber 2003b:202).

Weber er her inspireret af Nietzsches diagnose af modernitetens vilkår, hvor det moderne menneske efter Guds død må give afkald på alle moralske, teologiske, filosofiske eller historiske a priori for i stedet hengive sig til kontingente og stridende fortolkninger. På den ene side indebærer moderniteten altså diskontinuitet. På den anden side fremhæver Weber, med inspiration fra Nietzsche, en kontinuitet mellem kristendommens vilje til sandhed ${ }^{2}$ og det moderne samfunds krav om rationel beherskelse af såvel den indre som den ydre natur. Kristendommens 

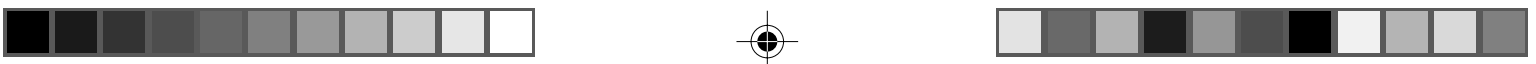

etos udmønter sig i en uafviselig sandhedssøgen og krav om rationel verdensbeherskelse og kommer hermed på paradoksal vis til at bidrage til affortryllelse og sekularisering af verden: „Og ikke blot den teoretiske tænkning, der berøvede verden dens magi, men netop også den religiøse etiks forsøg på at rationalisere verden førte i denne retning“"(Weber 2003c:355). I sidste ende kommer den vilje til sandhed, som udsprang af kristendommen, til i sin konsekvens at underminere religiøse begrundelser baseret på værdier. ${ }^{3}$

Med „de ophøjede værdiers tilbagetrækning“ fra det offentlige rum står det moderne menneske således med en dobbelttydig frihed. Det er "frisat" $i$ en affortryllet verden, hvor det selv må vælge sine værdier. Men for Weber er faren, at tabet af mening og værdier medfører, at individet enten reaktionært flygter ind $\mathrm{i}$ traditionalisme eller lader sig omslutte af den instrumentelle rationalitet, som i stigende grad præger både de politiske og videnskabelige institutioner. Moderniteten frembringer således på den ene side et subjekt, som har installeret en søgen efter det etisk rigtige liv og besidder potentialet for selv at fastsætte sine værdier, men på den anden side synes moderniteten samtidig at udradere muligheden for at fastsætte og forfølge værdier. Det moderne subjekt er hos Weber frisat til at fastsætte egne værdier, men står i konstant fare for at falde tilbage til traditionalisme eller blive gennemtrængt af markedets, bureaukratiets eller politikkens „etisk neutrale" formålsrationalitet. Det mest overraskende, eller ubekvemme, i Webers genealogi er, at det er „den religiøse etik“" og den rationelle askese, der udpeges som afgørende for den affortryllelse og det værditab, som installeres som et iboende problem i det moderne menneskes subjektivitet.

\section{Norbert Elias: Magt og civilisering}

Nobert Elias' arbejde indskriver sig i Webers problematik, for så vidt som et kernetema hos Elias er udviklingen af det europæiske menneskes ,personlighedsstruktur". Elias hævder, at den europæiske historie er præget af en gradvis bevægelse imod en stadig mere intensiv selvbeherskelse. Kroppen, lidenskaberne, indskydelserne og begæret underlægges en kraftigere selvkontrol i takt med civiliseringsprocessen - en proces, som pågår fra middelalderen og frem og er kendetegnet ved statens monopolisering af voldsudøvelsen og fremkomsten af stadig længere kæder af social interdependens. Elias og Weber anlægger beslægtede diagnoser af den europæiske historie som præget af en transformation fra en social orden baseret på ydre tvang $\mathrm{i}$ form af suveræn magt og traditionelt herredømme til en moderne orden, som snarere baserer sig på selvtvang og rationellegitimt herredømme. Men den tydelige Weber-inspiration i Elias' emnevalg og 

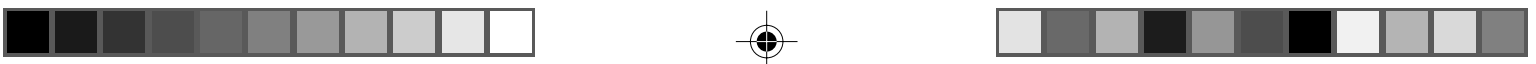

modernitetsanalyse betyder ikke, at han også forfølger en weberiansk analysestrategi.

Det skal slås fast, at Elias næppe kan betragtes som en egentlig modernitetskritiker a la Weber eller Foucault. Hans mål var ikke at formulere en diagnostisk kritik af det moderne samfund, men derimod at udvikle en ,processociologi“, som kunne tilvejebringe en mere sand forståelse af sociale processer. Især ville han påvise, hvordan sociale processer og psykiske strukturer er uløseligt forbundne. Undersøgelsen må ikke stoppe ved de sociale strukturer, men bør, som Elias formulerer det i The Civilizing Process, undersøge „... transformationen af både personlighedens psykiske struktur og den samlede sociale struktur" (Elias 1994:411). Man kan således sige, at Elias søger at komme tættere på spørgsmålet om subjektets konstituering end Weber. ${ }^{4}$ Elias stiller skarpt på, hvordan forandringer af specifikke sociale relationer og disses beskaffenhed $i$ sig selv kræver nye adfærdsmåder af de involverede aktører og hermed fremelsker bestemte personlighedsstrukturer. Elias understreger, at det drejer sig om på én gang at lave sociogenese og psykogenese. Man må gøre op med forestillingen om homo clausus - en forestilling om mennesket som en lukket størrelse, der ifølge Elias har domineret filosofien, sociologien og historievidenskaben: „Så længe vi anskuer det enkelte menneske som en fra naturens hånd lukket beholder med en ydre skal og en kerne gemt indeni, kan vi ikke begribe muligheden for en civilisationsproces, som omfatter mange generationer, og i løbet af hvilken det enkelte menneskes personlighedsstruktur forandres" (Elias 1994:480). Mennesket er ikke en lukket, men en åben struktur, som så at sige formes i kraft af historiens specifikke processer.

Elias' bidrag til det moderne subjekts genealogi skal først og fremmest udlæses af hovedværket The Civilising Process og i forstudiet The Court Society. Her påviser Elias en forbindelse mellem det moderne subjekt og dets førmoderne ophav ved at tegne en linje tilbage til de tidlige europæiske hofsamfund. Bøgerne beskriver en civilisationsproces, som finder sted fra det 12. til det 18. århundrede, og som ifølge Elias medfører en transformation af det vesteuropæiske menneskes psykiske struktur. Der er tale om en empirisk udfoldelse af Elias' begreber om sociogenese og psykogenese, hvor hoffet med dets særlige betingelser for personlighedsdannelse anskues i relation til bredere samfundsmæssige processer, som fører til dannelsen af de absolutistiske monarkier og en senere udbredelse af hofrationaliteten. Elias' analyse af hofetikken i The Court Society beskriver detaljeret, hvordan denne figuration fremelsker en bestemt psykisk struktur, eller habitus, hos individerne. Hofsamfundet bliver i Elias' optik et historisk prægningsapparat, hvis virkninger rækker langt ud over dets levetid, idet det efterlader et særligt aftryk på den moderne subjektivitet (Szakolczai 2000:127). 

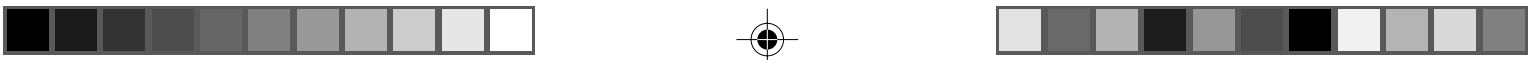

Det ,sociogenetiske“ udgangspunkt er, at der med overgangen fra fyrstendømmer til større territoriale enheder sker en magtkoncentration hos kongerne, som skaber særlig følsomme spændingsforhold i de europæiske hoffer. For at kunne agere i de magtkampe og intriger, der opstod i et netværket omkring kongen, måtte medlemmerne af hofadelen tilegne sig etiketten. Spillet om at positionere sig for at opnå kongens gunst foregik nemlig gennem en forfinet etikette for selvfremførelse. De etiketter, som blev brugt til at differentiere sig fra ikke-adelige og til at markere relationen til enhver højere eller lavere i hierarkiet, påtvang udøverne selvdisciplin og kontrolleret båndlæggelse af følelserne - en særlig hofrationalitet: „Nødvendigheden af at distingvere sig fra andre og kæmpe for sine muligheder ved hjælp af relativt fredelige midler, gennem intriger og diplomati, krævede en båndlæggelse af følelser, en selvdisciplinering og selvkontrol, en særlig hofrationalitet" (Elias 1994:190).

Der er flere ting at bemærke om den magtanalyse, som Elias udlæser af hoffigurationen. Først og fremmest er der tale om et sæt af magtrelationer, som stiller krav til alle - selv kongen - om at udøve en rationaliseret og konstant afmålt selvfremførelse (Elias 1998:90). I analysen viser Elias, hvordan strukturen etiketteritualerne - hele tiden må udøves af aktørerne. Denne udøvelse tenderer mod at reproducere positioner og ritualer, eftersom alle søger at undgå forandringer, som ville kunne medføre statustab. Når en aktør fremviser etiketten, låses den relaterede aktørs handlingsrum.

Men på den anden side er det netop ved at agere strategisk i forhold til etiketten og forsøge at forskyde den, at den enkelte aktør kan hævde sig og opnå en bedre position. Det er kampen om prestige, dvs. kravet om synlighed, kravet om konstant at distingvere sig, som giver hoffigurationen sin dynamik. Hermed viser Elias, hvordan hofsamfundet var præget af to modsatrettede tendenser. På den ene side tendensen mod rigiditet, fastlåsning og determinans. På den anden side en konstant nervøs bevægelse affødt af magtkampen om status og indflydelse. Hoffet bliver altså en struktur, som er i beveegelse. Aktør og social struktur skabes i en art samtidighed i denne historiske praksis. Hermed præsenterer Elias et tidligt og meget overbevisende bud på en overskridelse af sociologiens klassiske strukturaktør-problem.

Der er yderligere et afgørende træk ved hofsamfundet, nemlig det absolutte fravær af adskillelse mellem det offentlige og det private. ${ }^{5}$ Det er sigende, at Elias starter sin beskrivelse af hofetiketten med at notere placeringen af kongens soveværelse i hjertet af slottet. Denne placering udtrykker netop, hvordan kongens mest private handlinger anvendes som symbolske tegn, der indikerer hofmedlemmernes plads i den sociale orden. Soveværelset fungerede som ,... scene for et besynderligt ritual, næppe mindre højtideligt end en statslig ceremoni“ (Elias 

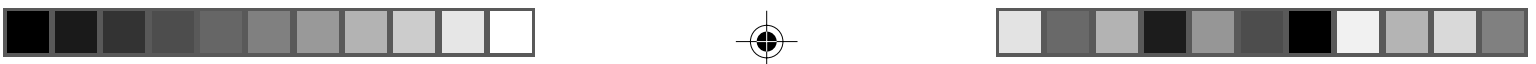

1998:83). Denne objektivering af det personlige satte ganske særlige betingelser for personlighedsdannelsen. Hvad et individ var, blev bestemt af den måde, hvorpå individet blev reprasenteret $\mathrm{i}$ den rituelle orden.

Individet måtte forme sin identitet $\mathrm{i}$ brydningspunktet mellem sin egen selvpræsentation og den anerkendelse eller miskendelse, som andre tildelte denne repræsentation (Chartier 2003:271). Eller for at sætte det endnu mere på spidsen: I hoffigurationen kan aktøren ikke være aktør uden at træde ind i de givne repræsentationer. Individet er nødt til konstant at repræsentere en forfinet prestigesymbolik for at eksistere i denne figuration. Hermed skabes et dobbeltblik hos individet - eller sagt i Goffmans termer: Aktøren iagttager både situationens rituelle symbolik og iagttager sin egen frontstage i forhold til den første iagttagelse. Hofsamfundet skaber hermed en ,psykologisk“ mennesketype, som altid anskuer sig selv relationelt og selvobjektiverende: „Set fra dette perspektiv er det ikke vanskeligt at forstå den afmålte attitude, de kalkulerede gestikker, de konstante nuancer i talen, kort sagt, den særlige form for rationalitet, som blev 'second nature' for medlemmerne af dette samfund“ (Elias 1998:93). I Elias' generelle tese om civilisationsprocessen optræder hofsamfundet som en afgørende social figuration, som stiller krav om nye adfærdstyper og hermed installerer hofsamfundets rationalitet som en ,second nature“. Etableringen af denne ny personlighedsstuktur markerer for Elias en helt afgørende tildragelse i den europæiske civilisations historie. Det moderne, selvobjektiverende og selvovervågende subjekt får hermed en kompleks genealogi, som rækker tilbage til de europæiske hofsamfunds eksistensbetingelser.

\section{Foucault og den moderne humanisme}

Det er muligt at læse Foucaults arbejde som en udfoldelse af Webers tematik om samfundets rationalisering og menneskets objektivering i det moderne samfunds institutioner og videnskaber. Vi kan sige, at i Foucaults optik udmønter den kristne vilje til sandhed sig i disciplinære interventioner og objektiverende diskurser, som indgår i gensidigt befrugtende institutionelle regimer. Foucaults strukturalistiske afsæt betyder, at der ikke er tale om en art indlevende verstehen af den personlighedstype, som har inderliggjort en protestantisk kaldsetik. Der er heller ingen tilløb til mikrointeraktionistisk analyse af, hvordan sociale figurationer skaber bestemte ,personlighedsstrukturer“. Foucaults gennemgående spørgsmål er, hvordan det moderne menneske erkender sig selv, og hvordan denne erkendelse er forbundet med magtmekanismer. Det moderne subjekt er hos Foucault en dobbelt størrelse, der på én gang gør sig selv til subjekt for al viden og til objekt for diverse vidensstrategier (Foucault 2006). 

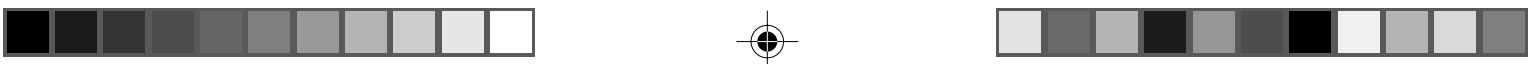

For Foucault formuleres det problematiske ved moderniteten ikke som et spørgsmål om, at den instrumentelle rationalitet reducerer værdispørgsmål. Problemet er snarere, at kristendommens vilje til sandhed udmønter sig i hegemoniske humanvidenskabelige diskurser og styringsstrategier. Og Foucaults genealogier kan derfor siges at være drevet af et ønske om at specificere og angribe de former, som denne vilje til sandhed antager.

I Overvågning og straf kommer denne kritik tydeligt til udtryk. Bogen er ikke blot en genealogi over det moderne fængsel, men kan læses som en udfoldelse af, hvordan viljen til sandhed på et meget praktisk plan skaber (human)videnskabelige forestillinger om, hvad mennesket er for en størrelse. Foucault viser således, hvordan minutiøse disciplinære praksisser skaber et epistemologisk rum, hvorfra moderne humanvidenskaber udspringer og henter næring. Analyseobjekter som psyken, personligheden, subjektiviteten og bevidstheden er ikke substanser, som kan „befries“, men er snarere opstået i kraft af procedurer til at overvåge, regulere og straffe: „Af denne akkuratesse er den moderne humanismes menneske uden tvivl opstået" (Foucault 2002:157). Disse disciplinære teknologier, som søger at kontrollere, styrke og nyttiggøre menneskekroppen, havde eksisteret længe i blandt andet klostre, hæren og værksteder, men Foucault hævder, at der gennem det 17. og 18. århundrede sker en knopskydning til stadig flere områder af samfundet. Hermed opstår nye rum for observation af normalitet og afvigelse. Analysens ubekvemme kontinuitet består i, at det førmoderne samfunds moralske skel mellem godt og ondt synes at genopstå i de moderne videnskabers skel mellem sundt og patologisk, normalt og afvigende. Disciplinen accelererer denne sortering.

For det første virker disciplinering ved at fordele individer og anvise hvert individ en bestemt plads, således at ,man hvert øjeblik kan overvåge enhvers opførsel, vurdere den, sanktionere den, måle dens kvaliteter eller fortjeneste. Det er da en procedure til at erkende, beherske og anvende" (Foucault 2002:159). Ved at genopdage klostrenes celler skaber disciplinen et rum, som på én gang tjener styringsformål og er særdeles analytisk. Foucault viser, hvordan hospitaler, fabrikker og skoler organiserer sådanne funktionel-analytiske rum. For det andet anvendes der skemaer, som bringer orden i mangfoldigheder og hierarkiserer, blandt andet i skolen, hvor eleverne indplaceres i forskellige rangordner efter præstation, alder, flid, renlighed m.v. Igen skaber disciplinen et blik, som ikke blot er funktionelt ordnende, men samtidig er klassifikatorisk-epistemologisk ved at konstruere stadig flere ,typer“. For det tredje bliver eksamen en generaliseret teknik, som forener differentieret gennemsigtighed og sanktion. Både undersøgelseshospitalet og den ,eksaminatoriske“ skole igangsætter en hidtil uset notation og dokumentationsvirksomhed, som muliggør en videnskabelig objektivering af 

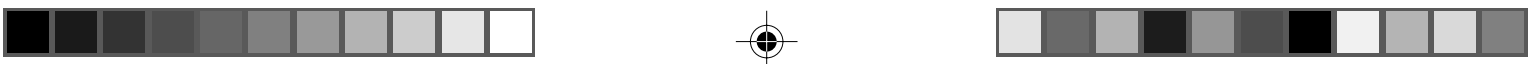

det menneskelige materiale. Denne videnskabelige objektivering fungerer samtidig som en normering, idet de bliver muligt at opstille normer på basis af sammenlignelige klassificeringer og beregnede gennemsnit (op.cit.:206). Iagttagelse, klassifikation, beregning, fastsættelse af norm og udøvelse af sanktion følges ad.

Overvågning og straf handler således i høj grad om relationen mellem viden og magt, om hvordan styringens anordninger afføder og muliggør en viden om de styrede, som igen indføres i styringspraksisserne. For straffesystemets vedkommende udskiftes lovbryderen med den afvigende - en figur, som opstår som resultat af kriminologiske observationer og psykiatriske kategoriseringer. „Fremkomsten af en videnskab om mennesket? Den skal sandsynligvis søges i de ikke særlig ærværdige arkiver, hvor det moderne system af tvangsforestillinger over kroppe, fagterne og adfærden har udviklet sig“"(op.cit.:207).

Foucaults genealogi kan siges at rette sit angreb mod de videnskabelige kategorier, som påberåber sig begreber om menneskets essentielle karakter og autenticitet - de ,normaltyper“, som hermed opstilles, og de magtformer, de er forbundet med. Ambitionen er en kritisk filosofisk praksis, som „... genindsætter alt det i tilblivelsen, som man havde troet udødeligt hos mennesket" (Foucault 2001:69). En ambition, som genealogien søger at indfri ved kritisk undersøgelse af forbindelsen mellem disciplinære praksisser og ,humanismens epistemologi“. Hver gang denne „teknovidenskab“ opstiller en type - den kriminelle, den gale, den hysteriske kvinde - sætter Foucaults sin antihumanistiske kritik ind. Denne kritik er antihumanistisk, fordi Foucault har erkendt, at begreber om autenticitet og frisættelse af menneskelige potentialer har en tendens til at ,intensivere“ magtrelationerne. For Foucault er det moderne individ et væsen, som objektiverer sig selv med reference til diverse essensforestillinger og adskillelseskategorier såsom fornuft/galskab, normalitet/afvigelse og fri/ufri.

\section{Subjektforståelsen}

Vi er nu i stand til yderligere at specificere og sammenligne Webers, Elias' og Foucaults forståelse af, hvad der kendetegner det moderne subjekt. Hos Weber er det moderne vestlige menneske kendetegnet ved at have inderliggjort et etisk program for livsførelse, som oprindelig udsprang af religiøse værdier. Der er tale om installation af en verdsliggjort protestantisk kaldsetik. Webers skeptiskfascinerede dobbeltblik på det moderne samfunds rationaliserede institutioner hænger netop sammen med hans diagnose af dette subjekt. De moderne frisættende og lighedsskabende institutioner som blandt andet bureaukratiet kan på den ene side kun fungere i kraft af individer, som har inderliggjort en verdslig kaldsetik i form af selvfornægtelse og rationel målforfølgelse. På den anden side 

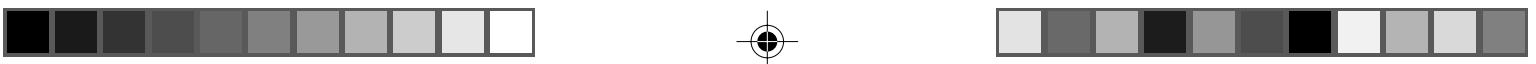

tenderer denne ,etiske væren“ konstant mod at blive gennemsyret af en instrumentel rationalitet, som er ,etisk neutral“. Det moderne individs eksistentielle grundproblem består hermed $\mathrm{i}$, at det søger efter mening i form af den etisk rigtige væren, men overalt mødes af rationaliserede institutioner. Problemet er, at det moderne bureaukratiserede og videnskabsbaserede samfund skaber en blindhed over for diskussioner om grundlæggende værdispørgsmål og etik - spørgsmål, som tenderer til at blive omformet til teknisk-instrumentelle problemer. ${ }^{6}$

Hos Elias er udgangspunktet ikke et subjekt, som har installeret en ,ejendommelig pligt til sin gerning", men snarere et subjekt, som må underlægge sig selv et krav om at udøve rationel selvfremførelse under indtryk af figurationers flukturerende magtbalancer. Sat på spidsen kan vi sige, at mens Webers subjekt byder sig selv at være rationelt som inderliggjort kaldsetik, udstyres Elias' subjekt med selvobjektiverende rationalitet som resultat af overlevelseskrav i den sociale figuration. Subjektet må repræsentere sig selv i de former, som nu engang er bydende i figurationen. Derfor behøver Elias ikke, som Weber, at lave indlevende fortolkning af $\mathrm{fx}$ calvinistens psykiske konstitution. Elias' analytik antager en mere strukturalistisk karakter, hvor strukturen (her i form af etiketten) i høj grad sætter subjekterne, som imidlertid holder strukturen i bevægelse i kraft af deres strategiske opereren. Når man ser gennem Elias' figurationsbegreb, skærpes blikket således for, hvordan subjektivitet skabes, ved at individer spiller sammen i figurationelle magtrelationer. Samtidig forbindes figurationerne til bredere sociale processer, som bidrager til at forklare figurationernes karakter og opkomst. Til gengæld må man søge forgæves efter et overbevisende bud på spørgsmålet om, hvad der kunne kendetegne en etisk væren som moderne menneske.

Foucaults analyser fremviser ligesom Webers og Elias' et moderne subjekt, der objektiverer sig selv. Foucault og Weber deler Nietzsches tese om, at denne selvobjektivering er drevet af en vilje til sandhed overleveret fra den kristne kirke - om end denne genealogiske linje er mindre dominerende og entydig hos Foucault. Hvad Foucaults optik særligt får sat i fokus, er den ,spidsfindige kombination", som opstår, når den kristne bekendelsesteknik (pastoralledelse) kombineres med juridisk-politisk suverænitetsdiskurs (Foucault 1982:213). Det moderne subjekt er et objektiveret subjekt, som er underlagt imperativet om for enhver pris at fremsige sandheden om sig selv - en sandhed, som de moderne ,pastorer“" skal bistå med at realisere gennem terapi, seksualrådgivning, psykologbistand, empowerment m.v. En styrke ved Foucaults analytiske optik er, at den retter sig mod de særlige eksistensbetingelser, som gælder i „liberale figurationer“". Når det moderne menneske bliver objektiveret og objektiverer sig selv, sker det således med reference til liberale begreber om selvrealisering og myndiggørelse (Villadsen 2004). Samtidig producerer liberal styring hele tiden inddelinger mellem individer 
og inde $i$ individer (Foucault 1982:208). Det moderne subjekt er hos Foucault et subjekt, som objektiveres og ledes mod selvobjektivering med reference til teknovidenskabens normaltyper.

Men kan vi komme en tak tættere på, hvad det er for en diagnose af det moderne menneske, som de tre fremfører? Og hvilke kritikpunkter kan rejses imod dem? Hos Weber har vi set, hvordan han bekymret forudskikker opkomsten af en mennesketype, som er ude af stand til at sætte værdier og handle etisk ansvarligt, fordi det er indfanget i rationalitetens jernbur. Rationaliseringen synes at udgøre en uomgængelig envejsbevægelse. Man kan indvende, at denne meget negative modernitetsdiagnose skyldes Webers problematiske forståelse af rationalitet. På den ene side taler Weber om at undersøge den vesterlandske rationalismes særlige egenart - genealogisk. På den anden side fremfører han flere steder den idé, at andre religioner „,båndlægger“ og „hæmmer“ realiseringen af praktisk rationalitet (Weber 1995:13). Weber synes hermed at komme til at operere med en art antropologisk konstant, der udstyrer mennesket med en iboende praktisk og meningssøgende handlen. Han installerer hermed en grænse for den historiskinstitutionelle opløsning af sine subjekter og kan beskyldes for en art etnocentrisme, der antager eksistensen af et potentielt (europæisk-vestligt) rationelt „dybdesubjekt", som gemmer sig under diverse kulturelle blokeringer.

En af attraktionerne ved Elias er, at han med sine begreber tilbyder en slags forbindelse mellem Weber og Freud, mellem brede sociale processer og den historiske udvikling af et overjeg (Krieken 1989:193). Mens Freud betragtede overjeget som en universel installation af social tvang i det ubevidste, anskuer Elias det som produkt af specifikke sociale betingelser, der er opstået historisk. To ting skal imidlertid påpeges her. For det første kan Elias anklages for ikke at være helt konsistent i sin subjektforståelse. Han ønsker på den ene side at gøre op med ethvert begreb om den ,menneskelige natur"ved at vise habitus' indlejrethed i sociale processer. På den anden side anvender han (måske netop på grund af Freud-inspirationen) begreber som ,,spontanitet“, ,instinkt“, ,fortrængning“ og „,selvtvang“, som indikerer, at han opererer med et slags oprindeligt hobbesiansk, driftsstyret menneske. For det andet skal vi bemærke, at opgøret med det lukkede subjekt - eller forestillingen om homo clausus - for Elias er et rent videnskabeligt opgør, ikke et kulturrelevant eller samtidsdiagnostisk. At det moderne subjekt fejlagtigt tænker sig selv som adskilt fra sin omverden ved at tænke gennem en subjekt-objekt-relation, udgør hos Elias et videnskabeligt problem. Elias' sociologi skal videnskabeligt påvise, at homo clausus-forestillingen er en illusion, som de moderne subjekter er låst inde i på samme måde, som hoffets medlemmer er låst inde i hoffigurationen. Når denne forestilling er tilbagevist, muliggøres mere „realitetskongruente“ forståelser af individ og sociale processer. 

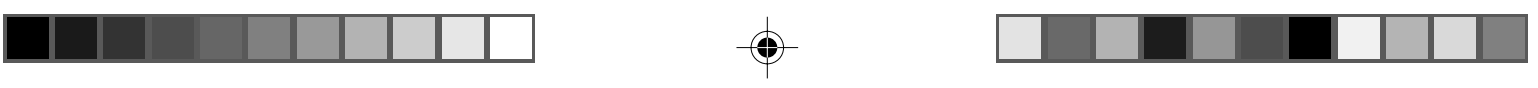

Hvilke formål Elias' processociologi skal tjene politisk, moralsk eller etisk står imidlertid åben hen.

Hos Foucault er den kritiske ambition derimod eksplicit, idet problemet er, hvordan menneskets objektivering af sig selv er forbundet med magtvirkninger. Og som sagt er Foucault meget opmærksom på de magtvirkninger, som kommer i spil i forbindelse med diskurser, som hævder at frigøre eller realisere menneskets „grundlæggende natur“. Det er måske af denne årsag, at Foucault synes at være den, som mest konsekvent gør op med enhver antropologi for det menneskelige subjekt - og med antropologi mener jeg her diverse grundantagelser om, hvad mennesket er, uafhængigt af historien. Han undgår næsten konsekvent at sige noget om, hvad der kendetegner mennesket, for i stedet at beskrive de måder, hvorpå det moderne menneske har gjort sig til subjekt ved at objektivere sig selv. Også her kan der dog gøres indvendinger. For det første: Med sit ønske om gøre det muligt for den enkelte at ,gøre sit liv til et kunstværk“ synes Foucault ansvarsløst at overlæsse værdibestemmelsen og de etiske spørgsmål til det enkelte individ. Det bliver vanskeligt at se, hvordan der skulle kunne vokse et „vi“ eller en kollektiv moral ud af Foucaults filosofiske praksis. Desuden kan tilføjes, at Foucaults ideal om et ,selvskabende“ og „,selvtransformerende“ subjekt efterhånden passer som hånd i handske med neoliberale ledelsesformer, som har indoptaget den poststrukturelle kritik og tænkning (Villadsen 2002). For det andet kan der stilles spørgsmålstegn ved, hvad det er for universalistiske subjektforestillinger, som Foucault formår at problematisere. Baudrillard (1982) har hævdet, at Foucaults metode begrænser genstandsområdet og radikaliteten af hans kritik: Eftersom den genealogiske strategi kræver en vis afstand til de undersøgte diskurser (man kan ikke undersøge sit eget arkiv), er Foucault tvunget til at rette sit kritiske blik mod diskurser og institutioner, som allerede er blevet fortid. De aktuelt virkende diskurser kan han imidlertid ikke kritisere, og det bliver derfor en kritik, som altid kommer for sent.

Et sidste punkt skal rejses i relation til de tre teoretikeres subjektforståelse, nemlig hvad Pritchard (1998) har kaldt „tykkelsen“ af subjektiviteten. På den ene side betragter foucauldianere subjektivitet som noget relativt tyndt, som formes i kraft af forskellige typer bearbejdning og selvbearbejdning. På den anden side står Weber, Elias og psykologisk inspirerede teoretikere som Frankfurterskolen, som tenderer mod at se subjektiviteten som „tykkere“, idet de betragter de sociale relationers indlejring i den menneskelige habitus som mere dyb, stabil og fast forankret. Det er da også karakteristisk, at Elias taler om, hvordan en figurationelt frembragt psykisk struktur bliver ,,second nature“, ,et automatisk, blindt fungerende apparat af selvkontrol" (Elias 1994:446). Men den afgørende forskel er øjensynligt, at Foucault aldrig hævdede, at han beskrev, hvordan individer faktisk blev formet, 

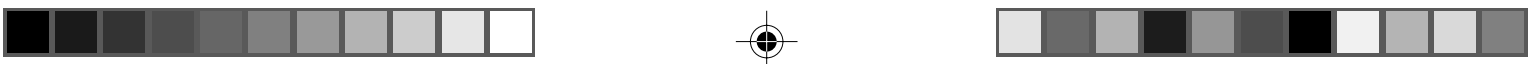

men derimod (klogeligt?) holdt sig til at beskrive, hvordan det sociale havde været forsøgt ordnet med henblik på at påvirke individer og individers selvstyring. Analysen i Overvågning og straf er da heller ikke en beskrivelse af det disciplinerede individ som fakticitet, men derimod en beskrivelse af, hvordan det sociale søges normeret eller disponeret med henblik på, at et bestemt subjekt (det selvforbedrende) skal opstå. Der er her en forskel i krav om realisme, som jeg vil berøre nedenfor.

\section{Sociologi versus genealogi}

Vi har set, hvordan Weber, Elias og Foucault alle leverer en kritik af det moderne subjekt - henholdsvis det verdsliggjorte kaldsmenneske, homo clausus og det selvobjektiverende subjekt - ved at historisere det og vise dets opkomst i etiske praksisser, figurationer og teknologisk-diskursive regimer. Vi har også set, hvordan de alle mener, at fortidens fremmedhed kan hjælpe os med at forstå og reflektere over vores nutid. Af denne årsag er der flere historiske sociologer, som har ønsket at sammentænke de tre, enten som led i en bestemmelse af en bestemt type kritisk eller „refleksiv“ historisk sociologi (Szakolczai 2000), eller som led i en belysning af konkrete spørgsmål såsom straffens udvikling (Spierenburg 2004) eller selvdisciplinens opkomst (Krieken 1989). Sådanne forsøg på sidestilling har en tendens til at overse grundlæggende forskelle mellem Webers og Elias' sociologi på den ene side og Foucaults genealogi på den anden - mellem en tilgang, der indskriver sig i en klassisk sociologisk tradition, og en tilgang, som snarere indskriver sig i en filosofisk/epistemologisk tradition. Jeg vil fremhæve nogle punkter, hvor disse forskellige traditioner adskiller sig afgørende fra hinanden.

For det første efterspørger sociologien generalitet og kausalitet i sine forklaringer, mens genealogien hverken ønsker eller mener sig i stand til at levere dette. At ville destabilisere og ryste samtidens selvfølgeligheder er ikke det samme som at ville beskrive eller forklare et samfund (Larsen 2000:147). Hos både Weber og Elias ligger vægten på forklaring af historiske fænomeners opkomst - den særlige vesterlandske rationalisme og det selvdisciplinerede menneske. Udgangspunktet hos begge er, at historien er et kompleks af samvirkende processer, og at man må undersøge sammenhængene mellem adskillige brede processer over lange tidsforløb. Det er dette perspektiv, som Weber forfølger i sine analyser af den vestlige kapitalismes opkomst, og som Elias forfølger i Civilisationsprocessen. I modsætning hertil afviser Foucault at arbejde med kausale forklaringer. Hans mål er ikke at levere udtømmende, sande historiske beskrivelser, men snarere at skabe ,sandhedseffekter" i sin samtid. Når Foucault ironiserende taler om at „multiplicere årsagsforklaringer“ (Foucault 1991:76), er målet således 
næppe at opnå større forklaringskraft, men snarere at inddrage beskrivelser, som muliggør en anderledes kritisk belysning af det valgte fænomen. Kritikere af Foucaults mangel på realisme og udtømmende analyse synes at overse, at Foucault ikke som udgangspunkt eftersøger forklaringer, men snarere udøver en bestemt kritisk filosofisk praksis på basis af historisk materiale.

Denne forskel mellem den sociologiske og genealogiske tilgangs grundlæggende ærinder afspejler sig for det andet $i$ diskussioner af analytiske styrker og svagheder hos de tre teoretikere. Flere har påpeget, at Foucaults brudvise historieskrivning står i kontrast til Webers og, især, Elias’ afdækning af langstrakte og overgribende processer. Foucault fremhæver derimod brud i sine genealogier og udtaler da også, at han på ingen måde eftersøger en underliggende kontinuitet, som ,hemmeligt animerer" historiens fremtrædelser (Foucault 2001:63). Når han fremviser kontinuiteter, sker det som oftest ved at beskrive, hvordan en bestemt magtform eller magtteknologi videreføres og genindskrives i en ny kontekst - jævnfør fx hans påstand om, hvordan den kristne styringsteknologi, der kræver bekendelse af sandhed, er blevet videreført i moderne styring. ${ }^{7}$

Endelig synes forskellen mellem sociologi og genealogi for det tredje at udmønte sig i forskellige magtbegreber hos de tre teoretikere. Weber, Elias og Foucault er enige om, at der er magt i enhver social relation. De er også fælles om at anlægge et konfliktperspektiv på historien, idet de (særlig Weber og Foucault) med inspiration fra Nietzsche betoner undersøgelsen af de stridende kræfter, hvorfra en særlig mennesketype med en særlig moral kan opstå. Weber taler om den „,konstellation af kræfter", hvorudfra den kapitalistiske ånd eller en særlig personlighedstype er fremkommet. Desuden beskriver han kapitalismen som en formende kraft, som ingen kan undslå sig (Weber 1995:116). Hos Elias er spørgsmålet, hvordan figurationens formende magtspil sætter et blivende præg på personligheden som habitus (Elias 1994). Og Foucault siger, at han vil vise, hvordan „den moderne sjæl“" (og humanvidenskabens forestillinger om, hvad den rummer) er opstået ud af et felt af praktiske metoder til afstraffelse, overvågning og beherskelse (Foucault 2002:44). I denne henseende er det altså muligt at sidestille de tre, for så vidt som de anskuer subjekters opkomstbetingelser som komplekser af kræfter og magtrelationer (Szakolczai 2000:123).

Går vi lidt tættere på deres magtbegreber, kan vi dog igen udpege en forskel mellem, hvad man kunne kalde en sociologisk magtforståelse hos Weber og Elias og Foucaults mere epistemologiske opfattelse. Weber og Elias tager udgangspunkt $i$ en handlingsteori - det er aktører, som via deres intentionelle handlinger skaber ikke-intenderede processer/strukturer, som hverken kan gennemskues eller kontrolleres. Webers calvinist skaber netop via sin intentionelle handling kapitalismen som ikke-intenderet resultat. Herudover arbejder Weber desuden med en socio- 

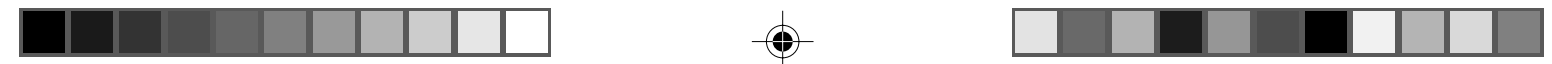

logisk magtanalytik, som udspringer af hans metodologiske individualisme: Individets magt eller „livschancer“ skal anskues i relation til den specifikke historisksamfundsmæssige fordeling af magtressourcer i form af klasseposition, standsmedlemskab og politisk organisering (Weber 2003a). Elias' figurationsbegreb anlægger ligeledes et sociologisk perspektiv på magt, idet magten så at sige udspringer af den måde, hvorpå mennesker fordeler ressourcer. Elias siger: „I virkeligheden er det, vi kalder 'magt', et aspekt af en relation, af enhver menneskelig relation. Det har noget at gøre med det forhold, at mennesker som grupper eller individer kan tilbageholde eller monopolisere det, som andre har brug for-mad, kærlighed, mening, beskyttelse mod angreb (dvs. sikkerhed), viden og en række andre ting“ (Elias 1984:215). Aktørerne opererer inden for figurationer, hvis magtmekanismer opererer relativt uafhængigt af de specifikke aktører. Magten er i den forstand depersonificeret.

Hos Foucault er magten også relationel og depersonificeret, men i en lidt anderledes forstand. Fokus er ikke på, hvordan aktører handler. Der er snarere tale om et epistemologisk spørgsmål om, hvordan det, der kan gøres, står i relation til det, der kan vides. Som vi så i Overvågning og straf skaber interventioner og anordninger felter, hvorfra vidensobjekter kan opstå. Eller bedre: Allerede eksisterende vidensformer og magtteknologier udgjorde en forudsætning for opkomsten af disciplinære institutioner, som efterfølgende gav mulighed for at etablere ny viden og nye kategorier af afvigere og kriminelle. Hos Foucault er det et netværk af udsagn, institutioner, teknologier og sociale praksisser, som udgør det (magt)felt, hvorfra styringsobjekter kan opstå (Villadsen 2006). Det er derfor, at Foucault kan tale om strategier, som er intentionelle, men som ingen dirigerer eller har opfundet.

De tre teoretikeres forståelse af magt og subjektivitet synes således igen at fremvise et skel mellem sociologi og genealogi. I sin mest programmatiske formulering arbejder Weber med et traditionelt magtbegreb, som vedrører A's magt over B, og selv om der er ansatser, skal man arbejde aktivt for at udlæse en mere moderne magtforståelse. Og med moderne magtforståelse mener jeg her et magtbegreb, hvor magt ikke blot er en styring, som A udøver over B, men snarere er en produktiv kraft, som er indlejret i vores sociale mikrorelationer, $\mathrm{i}$ vores selvforhold, $i$ vores samfundsinstitutioner og vores institutionaliserede praksisser. Elias udfolder i sin figurationsanalyse, hvad der ligner et produktivt magtbegreb, idet figurationens krav til selvfremstilling aktivt skaber en bestemt type subjekt med bestemte kapaciteter. Hermed foretager Elias en dekonstruktion af sit subjekt i produktivt formerende praksisser og selvpraksisser. Til gengæld blokerer hans generelle (freudiansk inspirerede) tese om civilisationsprocessen som stigende undertrykkelse af spontanitet for en konsekvent anvendelse af en produk- 

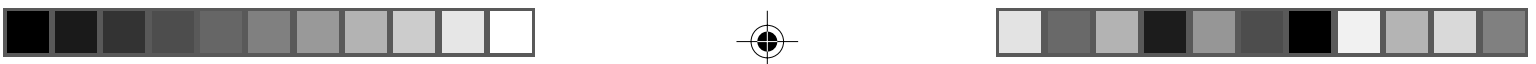

tiv magtforståelse. Dog ligner Elias' og Foucaults magtbegreber hinanden på så mange punkter, at frugtbare koblinger øjensynligt er mulige, $\mathrm{fx}$ ved at inkludere diskurs- eller teknologianalyse $i$ en figurationsanalyse eller ved omvendt at inddrage institutionelt forankrede magtrelationer mellem aktører i en genealogi.

\section{Konklusion}

Weber, Elias og Foucault er sammenlignelige i kraft af temaet om det moderne subjekts opkomst snarere end i kraft af deres filosofisk-videnskabsteoretiske udgangspunkter. Frem for alt har de forskellige fortolkninger af, hvilken funktion den videnskabelige praksis bør indtage. Weber søger at skabe en integrerende mellemvej mellem fortolkende og forklarende videnskab, og her bliver idealtypemetoden det objektivistiske element i historikerens subjektive fortolkning. Selv om man som videnskabsmand er udleveret til sit personlige valg om, hvad der fortjener ens engagement, bør man søge at afkøle sine passioner og konditionere sin iagttagelse metodisk, således at den bliver så objektiv som mulig. Videnskabsmanden bør erkende, at hans aktivitet baserer sig på valg, som ikke kan hente begrundelse fra andet end hans subjektive engagement og værdiorientering. Denne erkendelse af, at også videnskabens valg af genstandsfelt er drevet af værdistandpunkter, som altid står i konflikt med andre, bør ifølge Weber mane videnskabsmanden til „besindighed“ ${ }^{8}$ Den moderne videnskabsmand må afstå fra at optræde som profet i det sociale liv, men hvad han kan gøre er blandt andet at bidrage til at skabe klarhed over, hvilke konsekvenser forfølgelse af bestemte standpunkter har. Hermed kan man om videnskabsmanden sige, at ,han tjener en 'etisk' magt, nemlig pligten til at skabe klarhed og ansvarsfølelse“" (Weber 2003b:206). Modernitetens stående værdikonflikter kan ikke løses af videnskaben. Denne må indskrænke sin kritiske rolle til at tilvejebringe ,ubekvemme fakta“ om, hvad bestemte standpunkter indebærer, når de forfølges i deres konsekvens. Det kan hævdes, at Weber hermed havner $i$ en nihilisme, som betyder, at han bliver ude af stand til at udnytte sit arbejdes kritiske potentialer og effekter. Andre (fx Bild 1989; Bruun 1996) fastholder imidlertid, at styrken ved Webers videnskab netop er påpegningen af de uundgåelige værdikonflikter, som udgør det grundvilkår, hvorunder individet må træffe sine selvbestemte valg.

Elias hævder, at sociologen må stræbe efter at opnå „detachment“ fra sin nutid med dens interesser og konflikter for at blive i stand til at skrive en mere „objektadækvat" eller realitetsnær historie om den menneskelige udvikling. Elias (1987:223ff.) mener, at sociologien siden 2. verdenskrig har taget retræte til nutiden og hermed har mistet den erkendelse, som pionerer såsom Marx og Weber opnåede ved at anskue deres samtids problemer ud fra disse samfunds fortid og 

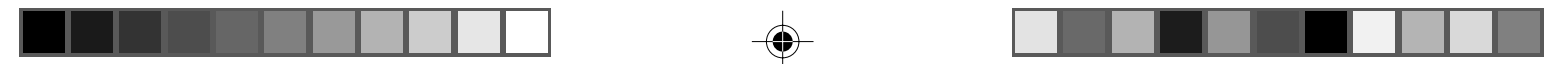

historiske udvikling. Sociologien er domineret af empiriske undersøgelser drevet af et følelsesmæssigt engagement i nutiden, ${ }^{9}$ og denne mangel på teoretisk forankring og videnskabelig distance forhindrer sociologien $i$ at begribe nutidens betydning som ,en forbigående fase i menneskelighedens langstrakte udviklingsproces“ (op.cit.:224). Man kan hævde, at Elias bekender sig til en slags ,,sofistikeret empirisme" (Layder 1986), som antager, at sociologien udvikler en empirisk funderet viden, som bliver stadig ,,mere omfattende, mere korrekt og mere adækvat“"(Elias 1978:53). Elias fremhæver netop figurationsanalysen som mere objektadækvat, idet den er i stand til at overvinde en række fastlåste problemer i samfundsvidenskaben: individ/samfund, voluntarisme/determinisme, forandring/stabilitet m.v. Elias synes at eftersøge et neutralt punkt uden for historien, som forskeren må bevæge sig hen imod ved at udvikle begreber, som er „objektadækvate“ i forhold til de processer, han beskriver.

I modsætning hertil tager Foucault som udgangspunkt, at iagttageren altid er indlejret, at han iagttager fra et punkt, som altid er „overdetermineret“ af diskurser, og at der ikke kan gives en neutral eller objektiv rekonstruktion af fortiden, som har revet sig absolut fri af disse diskurser. Enhver historie skrives altid under indtryk af sin samtids forestillinger, interesser, begreber og behov. Historikeren må derfor vælge, hvilke problemer der fortjener opmærksomhed, og skrive sin historie med henblik på, hvilke kritiske virkninger han ønsker at indføre i sin samtid. Foucaults genealogi tager eksplicit sit afsæt i specifikke konflikter og kampe for at undersøge, hvilke konsekvenser diverse konstruerede universalier og normaltyper har i bestemte nutidige (eller historiske) sammenhænge. Han taler om at lave „,indspil i spillet“, om at skabe ,forskydninger i vidensregimerne“ og om at finde de små sprækker, som kan holde diskursens principielle uafgørlighed fri af modernitetens fastlåsninger og ordensstrategier. Foucaults egne analyser udgør ikke en privilegeret diskurs hævet over alle andre eller en „sand“, videnskabelig afdækning af, hvad der gemmer sig bag den falske ideologi. Hans genealogier er snarere kritiske indspark i de konkrete historiske magtfelter, som har muliggjort dem.

Analytisk anlægger de tre tænkere forskellige blikke på verden - ja, vi kan måske sige, at de placerer sig på forskellige niveauer. Hos Weber er der tale om en modernitetskritik, som tenderer mod at anlægge et totaliserende blik, idet han taler om det moderne samfunds rationalisering som en art overgribende proces, der karakteriserer „den vesterlandske kultur“. Hos Elias er der tale om et mere afgrænset analytisk blik, idet han analyserer ,sociale figurationer" som historisk afgrænselige mønstre af afhængighedsrelationer. Med sit konfigurationsblik står Elias og kigger ned på sine aktører, som er låst inde i institutionaliserede magtrelationer, de hverken kan gennemskue eller bryde ud af. I Foucaults genealogier synes det analytiske blik at blive endnu mere „lokalt", idet opgaven er at oprulle, 

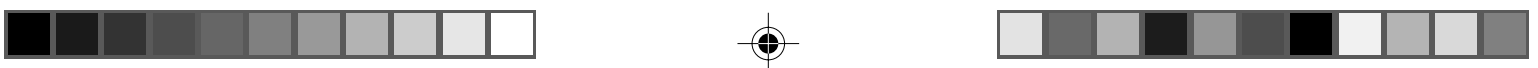

hvordan det moderne mennesket har gjort sig selv til objekt gennem specifikke disciplinære teknologier, videnskabelige diskurser og selvpraksisser. Foucault understreger, at han beskriver lokale rationaliteter, som opstår som svar på diverse konkrete problemer og utilsigtede virkninger. Han ønsker ikke at opløfte rationaliteterne til generelle typer eller modeller på virkeligheden, som hos Weber, og afviser at tale om rationalisering som overgribende (Villadsen 2002). Denne „lokale“ eller „regionale“ tilgang præger også Elias’ konkrete figurationelle analyser - som dog indsættes i en generel historieteori om stigende interdependens, opkomsten af den funktionelle arbejdsdeling m.v.

Som modernitetskritikere er det Weber og Foucault, der ligner hinanden mest. De ønsker begge at afstå fra at optræde som „lovgivere“ med adgang til retfærdigheden eller den endelige sandhed - udtrykt hos Weber med kravet om, ,værdiernes videnskabsfrihed“ og hos Foucault med begrebet om ,den specifikke intellektuelle“. Hos Weber kan videnskaben tilvejebringe ,ubekvemme fakta“ og klargøre konsekvenserne af at forfølge bestemte mål, og hos Foucault må den intellektuelle konstant tage bestik af, hvad der udgør ,den største fare“, og fremvise omkostningerne ved bestemte magt-viden-konstellationer. Elias mener, at sociologien skal isoleres fra nutidens lidenskaber og politik, men det er noget uklart, hvilke overvejelser der så skal styre sociologens emnevalg. Han nærer en tiltro til, at den moderne sociologi kan tilvejebringe en stadig mere „objektadækvat" viden om de sociale processer, således at deres værste virkninger kan imødegås rationelt. Hermed forfølger Elias en art evolutionistisk, positivistisk position, som i denne henseende fremstår mere gammeldags end Webers. Heroverfor består Webers og Foucaults grundlæggende fællesskab i deres synspunkt om, at intellektuel aktivitet skal være „,æærdirelevant“ "eller „livgivende“ $\mathrm{i}$ forhold til samtidens debatter og magtkampe. Begge er de inspireret af Nietzsches krav om, at „kun for så vidt historien tjener livet, vil vi tjene den“(Nietzsche 1994:36). Intellektuelt arbejde skal bidrage til at fremvise de uomgængelige værdikonflikter, som kendetegner moderniteten, og hermed belyse spørgsmålet om, hvilke begrænsninger og muligheder den vestlige modernitet rummer for at være menneske. Mens antropologisk forskning kan vise, at den vestlige forestilling om individet som en selvomsluttet enhed er en specifik kulturel konstruktion, kan den historiske sociologi udfordre os ved at fremvise de besynderlige historiske praksisser og institutioner, som formede denne forestilling. 


\section{Noter}

Jeg ønsker at takke følgende varmt for frugtbare kommentarer til tidligere versioner af denne artikel: professor Margaretha Järvinen, professor Heine Andersen, ph.d.-stipendiat Jakob Demant, post.doc.-stipendiat Christian Borch (alle Sociologisk Institut, Københavns Universitet), ph.d.-stipendiat Mads Peter Karlsen, Teologisk Institut, Københavns Universitet, samt tidsskriftets to anonyme referees.

1. Hvor oversættelser ikke foreligger på dansk, er citaterne oversat af forfatteren.

2. Nietzsche havde netop erklæret, at kristendommens kerne er viljen til sandhed (Nietzsche 1999:166).

3. Senest er diagnosen om affortryllelse blevet taget endnu et skridt videre af Vattimo, der hævder, at de moderne overbevisninger om fornuftens fremskridt har vendt sig mod sig selv. Fortællingerne om den moderne videnskabs evne til at afvikle myter fremstår nu selv som myter (Vattimo 2000:19).

4. Man kan med en vis ret hævde, at Weber, på trods af sin individualistiske handlingsteori, overvejende interesserede sig for brede sociale forandringer og større institutioner (religion, kapitalisme) uden nøjere at undersøge, hvordan de nye institutioner påvirkede individernes indre liv (Krieken 2003:138).

5. Hofsamfundets sammensmeltning af det offentlige og det private er det diametralt modsatte af Webers idealtype på rationaliseringens højeste form, nemlig bureaukratiet, som omvendt er kendetegnet ved en absolut adskillelse mellem det personlige og det professionelle. Dette ændrer dog ikke på, at også Weber trækker en genealogisk linje fra det rationaliserede kaldsmenneske tilbage til ,irrationelle“, førmoderne institutioner.

6. De rationaliserede institutioners ,etiske blindhed“ har været omdrejningspunkt for meget kritisk teori, og deres yderste konsekvenser beskriver Baumann i Modernity and Holocaust (1989), hvor det moderne bureaukratis evne til effektivt og etisk uengageret at implementere nazismens racehygiejne udfoldes.

7. Man kan muligvis med fordel tale om et temporalt perspektiv hos Elias over for et mere rumligt eller spatialt hos Foucault (Ogborn 1995:70).

8. Denne besindelse kræver, at forskeren forholder sig køligt til egne passioner ved at forfølge videnskabelige metoderegler, herunder anvendelse af idealtype-metoden. På denne måde indskriver Webers modernitetsdiagnose sig i selve hans metodologi: Der gives ingen endegyldige begrundelser for forskerens værdiorientering og engagement $i$ en bestemt problematik. Når der er truffet et subjektivt valg om at arbejde med et givent problem, bør forskeren imidlertid efterstræbe objektivitet. Webers krav til forskeren består således $i$ både at udvise engagement $o g$ hæderlighed, gøre sig klart, at der inden for videnskaben „,nu engang ikke gælder noget andet etisk krav end netop kravet om intellektuel hæderlighed" (Weber 2003b:211).

9. Elias anerkender, at sociologers forbindelse til grupper, der kæmper om magt og indflydelse, begrænser, hvor meget „detachment“" sociologien kan opnå. Men han argumenterer for, at en højere grad af tilbagetrækning fra nutidens politiske konflikter og lidenskaber er nødvendig, hvis sociologien skal blive i stand til at tilvejebringe en dybere forståelse af nutidens problemer - en forståelse, som kun kan opnås ved at placere disse problemer inden for menneskelighedens udviklingshistorie. 


\section{Litteratur}

Baudrillard, Jean

1982 [1977] At glemme Foucault. København: Biblioteket Rhodos.

Baumann, Zygmunt

1989 Modernity and Holocaust. Cambridge: Polity Press.

Bild, Tage

1989 Tvivlen om det rationaliserede samfunds fornuft - økonomi og samfund hos Max Weber. I: K.K. Klausen \& T.H. Nielsen (red.): Stat og marked - fra Leviathan og usynlig hånd til forhandlingsøkonomi. Charlottenlund: Jurist- og Økonomforbundets Forlag.

Bruun, Hans Henrik

1996 Værdi og værdifrihed i Max Webers sociologi. Dansk Sociologi 4(7):31-41.

Chartier, Roger

2003 Social Figuration: Reading Elias. I: E. Dunning \& S. Mennel (eds.): Norbert Elias. Volume 1. London: Sage Publications.

Collins, Randall

2000 [1986] Max Weber - personen og forfatterskabet. København: Hans Reitzels Forlag.

Comaroff, John \& Jean Comaroff

2001 On Personhood: An Anthropological Perspective from Africa. Social Identities $7(2): 267-83$

Elias, Norbert

$1984 \quad$ Knowledge and Power: An Interview by Peter Ludes. I: N. Stehr \& V. Meja (eds.): Society and Knowledge. New Brunswick, NJ: Transaction.

1987 The Retreat of Sociologists into the Present. Theory, Culture and Society 4(2-3).

1994 [1939] The Civilizing Process. Sociogenetic and Psychogenetic Investigations. Oxford: Blackwell Publishing.

1998 [1969] The Changing Functions of Etiquette. I: S. Mennel \& J. Goudsblom (eds.): Norbert Elias. On Civilization, Power and Knowledge. Chicago: University of Chicago Press.

Foucault, Michel

1982 The Subject and Power. I: H. Dreyfus \& P. Rabinow (eds.): Michel Foucault: Beyond Structuralism and Hermeneutics. Hemel Hemstead: Harvester Wheatsheaf.

1991 Questions of Method. I: G. Burchell et al. (eds.): The Foucault Effect. Chicago: University of Chicago Press.

2001 [1971] Nietzsche, genealogien, historien. I: M. Foucault: Talens forfatning. København: Hans Reitzels Forlag.

2002 [1975] Overvågning og straf: Fængslets fødsel. Frederiksberg: Det lille Forlag.

2006 [1966] Ordene og tingene: En arkæologi om humanvidenskaberne. Frederiksberg: Det lille Forlag.

Goffman, Erving

1962 Asylums: Essays on the Social Situation of Mental Patients and Others. Chicago: Aldine.

Hennis, Wilhelm

1983 Max Weber's „Central Question“. Economy and Society 12(2):135-80. 
Krieken, Robert Van

1989 Violence, Self-discipline and Modernity: Beyond the „Civilizing Process“.

Sociological Review 37(2):193-218.

2003 The Organisation of the Soul: Elias and Foucault on Discipline and the Self. I: E. Dunning \& S. Mennel (eds.): Nobert Elias. Volume 1. London: Sage Publications.

La Fontaine, J.S.

1985 Person and Individual: Some Anthropological Reflections. I: M. Carrithers, S. Collins \& S. Lukes (eds.) The Category of the Person: Anthropology, Philosophy, History. Cambridge: Cambridge University Press.

Larsen, Lars Thorup

2000 De unormales genealogi. Distinktion 1:144-7.

Layder, Derek

1986 Social Reality as Figuration: A Critique of Elias's Conception of Sociological Analysis. Sociology 20(3):367-86.

Mauss, Marcel

1985 [1938] A Category of the Human Mind: The Notion of the Person; the Notion of the Self. I: M. Carrithers, S. Collins \& S. Lukes (eds.): The Category of the Person: Anthropology, Philosophy, History. Cambridge: Cambridge University Press.

Mead, George Herbert

1934 Mind, Self and Society. Chicago: University of Chicago Press.

Mommsen, Wolfgang

1987 Personal Conduct and Societal Change: Towards a Reconstruction of Max Weber's Concept of History. I: S. Lash \& S. Whimster (eds.): Max Weber. Rationality and Modernity. London: Allen \& Unwin.

Nietzsche, Friederich

1994 [1874] Historiens nytte. København: Gyldendal.

1999 [1887] Moralens oprindelse: Et stridsskrift. Frederiksberg: Det lille Forlag.

Ogborn, Miles

$1995 \quad$ Knowing the Individual: Michel Foucault and Norbert Elias on Las Meninas and the Modern Subject. I: S. Pile \& N. Thrift (eds.): Mapping the Subject: Geographies of Cultural Transformation. London: Routledge.

Pritchard, Craig

1998 Identity Work: Moving the „Theory of the Subject“ from „Division“ to „Depth“ in Labour Process Analysis. Paper præsenteret på the $16^{\text {th }}$ International Labour Process Conference. Manchester School of Management.

Spierenburg, Petrus Cornelis

2004 Punishment, Power, and History: Foucault and Elias. Social Science History 28(4):607-36.

Szakolczai, Arpad

2000 Reflexive Historical Sociology. London: Routledge.

Taylor, Charles

1989 Sources of the Self: The Making of Modern Identity. Cambridge: Harvard University Press. 
Vattimo, Gianni

2000 [1996] Jeg tror at jeg tror. Frederiksberg: Anis.

Villadsen, Kaspar

$2002 \quad$ Foucault og liberalismekritik: Governmentality eller genealogi som

analysestrategi? Dansk Sociologi 3(13):77-98.

2004 Det sociale arbejdes genealogi: Kampen for at gøre fattige og udstødte til frie mennesker. København: Hans Reitzels Forlag.

2006 Genealogi som metode: fornuftens tilblivelseshistorier. I: O. Bjerg \& K. Villadsen (red.): Sociologiske metoder - fra teori til metode i kvantitative og kvalitative studier. Frederiksberg: Samfundslitteratur.

Weber, Max

1995 [1920] Den protestantiske etik og kapitalismens ånd. København: Nansensgade Antikvariat.

2003a [1915] Politiske fællesskaber: Magtfordelingen inden for fællesskabet: Klasser, stænder og partier. I: H. Andersen, H.H. Bruun \& L.B. Kaspersen (red.): Max Weber. Udvalgte tekster. Bind 2. København: Hans Reitzels Forlag.

2003b [1919]Videnskab som levevej. I: H. Andersen, H.H. Bruun \& L.B. Kaspersen (red.): Max Weber. Udvalgte tekster. Bind 2. København: Hans Reitzels Forlag.

2003c [1915] Indskudte betragtninger: Teori om religiøs verdensafvisnings stadier og retninger. I: H. Andersen, H.H. Bruun \& L.B. Kaspersen (red.): Max Weber. Udvalgte tekster. Bind 2. København: Hans Reitzels Forlag. 